\title{
Cancer-related microangiopathic haemolytic anaemia
}

\author{
Anthony A Donato, ${ }^{1}$ Salik Nazir, ${ }^{2}$ Niranjan Tachamo, ${ }^{1}$ Daniel Forman ${ }^{3}$
}

${ }^{1}$ Internal Medicine Department, Reading Health System, West Reading, Pennsylvania, USA ${ }^{2}$ Internal Medicine Department, Reading Hospital and Medical Center, West Reading, Pennsylvania, USA

${ }^{3}$ Hematology/Oncology, Reading Health System, West Reading, Pennsylvania, USA

\section{Correspondence to}

Dr Niranjan Tachamo, niranjantachamo@gmail.com

Accepted 22 November 2017

CrossMark

To cite: Donato AA, Nazir $S$, Tachamo N, et al. BMJ Case Rep Published Online First: [please include Day Month Year]. doi:10.1136/bcr-2017223382

\section{DESCRIPTION}

A 71-year-old woman with widely metastatic breast cancer to liver and bone marrow presented with 2 weeks of fatigue. Examination revealed a severely ill-appearing woman in moderate distress with icterus and jaundice. Laboratory investigations revealed profound anaemia (haemoglobin $5.2 \mathrm{~g} / \mathrm{dL}$ ) with appropriate reticulocyte response (14.4\%) and a normal platelet count $\left(207 \times 10^{9} / \mathrm{L}\right)$. Additional tests revealed a lactate dehydrogenase of $2997 \mathrm{IU} / \mathrm{L}$ (normal: 140-297 IU/L), negative direct Coombs antiglobulin, an undetectable haptoglobin level, elevated total bilirubin, newly elevated prothrombin time (19.7s, normal: <14.1s), elevated fibrin split products and D-dimer $(14.36 \mu \mathrm{g} / \mathrm{dL}$, normal: $<0.53 \mu \mathrm{g} /$ $\mathrm{dL})$ but normal fibrinogen level $(322 \mathrm{mg} / \mathrm{dL}$, normal:

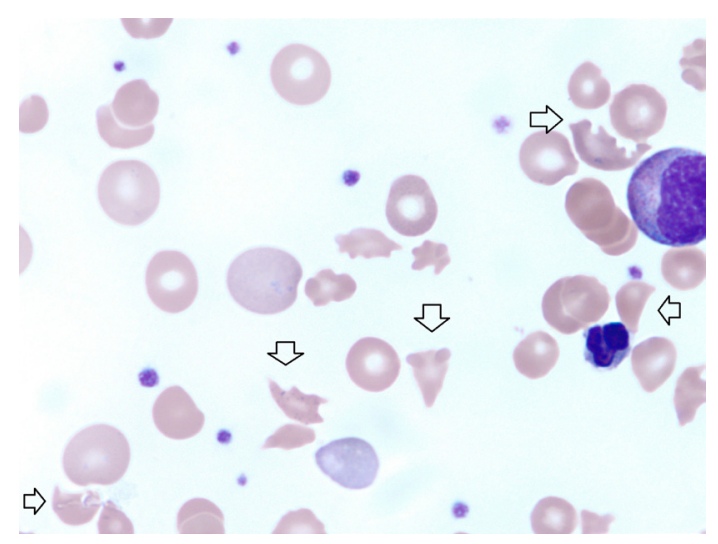

Figure 1 Arrows showing marked schistocytes.

\section{Learning points}

- Cancer-associated microangiopathic haemolytic anaemia (CR-MAHA) is a type of thrombotic microangiopathy that can occur in any solid malignancy including breast cancer.

- CR-MAHA is most commonly associated with gastric cancer, followed by breast, prostate and lung cancers.

$193-488 \mathrm{mg} / \mathrm{dL}$ ). Peripheral blood smear revealed marked schistocytosis (figure 1) with normal platelet count. The patient was diagnosed with cancer-associated microangiopathic haemolytic anaemia ${ }^{1}{ }^{2}$ with laboratory evidence of disseminated intravascular coagulation, and she passed away on comfort measures 24 hours after admission.

Contributors $A A D, S N$ and DF were involved in patient care and writing of the manuscript. NT was involved in the editing of the manuscript.

Competing interests None declared.

Patient consent Guardian consent obtained.

Provenance and peer review Not commissioned; externally peer reviewed.

(c) BMJ Publishing Group Ltd (unless otherwise stated in the text of the article) 2017. All rights reserved. No commercial use is permitted unless otherwise expressly granted.

\section{REFERENCES}

1 Govind Babu K, Bhat GR. Cancer-associated thrombotic microangiopathy. Ecancermedicalscience 2016;10.

2 Takabatake D, Oishi K. Microangiopathic hemolytic anemia associated with metastatic breast cancer: case report and literature review. Springerplus 2016;5.

Copyright 2017 BMJ Publishing Group. All rights reserved. For permission to reuse any of this content visit http://group.bmj.com/group/rights-licensing/permissions.

BMJ Case Report Fellows may re-use this article for personal use and teaching without any further permission.

Become a Fellow of BMJ Case Reports today and you can:

- Submit as many cases as you like

- Enjoy fast sympathetic peer review and rapid publication of accepted articles

- Access all the published articles

- Re-use any of the published material for personal use and teaching without further permission

For information on Institutional Fellowships contact consortiasales@bmjgroup.com

Visit casereports.bmj.com for more articles like this and to become a Fellow 